\title{
Benign Stenosis of Oesophagus: About 101 Cases in the Digestive Endoscopy Department of the General Idrissa Pouye Hospital (Dakar, Senegal)
}

\author{
Mamadou Ngoné Guèye1, Mame Anta Camara1, Gnagna Diouf', Salamata Diallo², \\ Cheikh Ahmadou Bamba Cissé1, Marème Polèle Fall2, Mame AïsséThioubou ${ }^{3}$, \\ Marie Louise Bassène ${ }^{2}$, Daouda Dia ${ }^{1}$, Mouhamadou Mbengue ${ }^{1}$
}

\author{
${ }^{1}$ Hepato-Gastroenterology Department, The Idrissa Pouye General Hospital, Dakar, Senegal \\ ${ }^{2}$ Hepato-Gastroenterology Department, The Aristide Ledantec Hospital, Dakar, Senegal \\ ${ }^{3}$ Hepato-Gastroenterology Department, The Ziguinchor Peace Hospital, Dakar, Senegal \\ Email: mamadoungone@yahoo.fr
}

How to cite this paper: Guèye, M.N., Camara, M.A., Diouf, G., Diallo, S., Cissé, C.A.B., Fall, M.P., Thioubou, M.A., Bassène, M.L., Dia, D. and Mbengue, M. (2022) Benign Stenosis of Oesophagus: About 101 Cases in the Digestive Endoscopy Department of the General Idrissa Pouye Hospital (Dakar, Senegal). Open Journal of Gastroenterology, 12, 19-26.

https://doi.org/10.4236/ojgas.2022.121002

Received: December 7, 2021

Accepted: January 17, 2022

Published: January 20, 2022

Copyright $\odot 2022$ by author(s) and Scientific Research Publishing Inc. This work is licensed under the Creative Commons Attribution International License (CC BY 4.0).

http://creativecommons.org/licenses/by/4.0/ (c) (i) Open Access

\begin{abstract}
Introduction: Benign oesophageal strictures are defined as narrowing of the oesophageal lumen not related to neoplastic pathology. They are frequently encountered during endoscopic practice and are often responsible for a reduction in the quality of life of patients due to the appearance of dysphagia. In sub-Saharan Africa, little data are available on these benign esophageal strictures. The objective of our study was to determine the sociodemographic, diagnostic and therapeutic aspects of benign oesophageal strictures in a digestive endoscopy centre in Senegal. Patients and Methods: This was a retrospective, descriptive study analysing reports of upper GI endoscopies performed between January 2015 and December 2017 in a hospital in Senegal. Reports that concluded to have non-neoplastic oesophageal stenosis were collated. Sociodemographic data, indications for and results of endoscopy, and therapeutic modalities were collected. These data were analysed using the Sphinx version 5 software. Results: We collected 101 cases of benign oesophageal stenosis, representing a prevalence of $2.1 \%$ in the endoscopy centre. The mean age of the patients was 34 years (range 2 and 83 years) with a median of 37.9 years. There was a female predominance with a sex ratio of 0.38 (73 females). Dysphagia, the main symptom, was present in 87 patients $(86.1 \%$ of cases) with a Dysphagia score greater than or equal to 2 in 51 patients (50.5\%). The average duration of this dysphagia, excluding caustic stenosis, was 4 years (extremes 1 and 15 years). Endoscopy revealed simple stenosis in 76 cases $(75.2 \%$ of cases). A membranous ring of the cervical oesophagus,
\end{abstract}


suggestive of the Plummer-Vinson syndrome ring, was found in 60 patients (59.4\% of cases) and was the primary cause; other aetiologies were dominated by caustic stenosis (19 cases), Schatzki rings ( 8 cases) and peptic stenosis (4 cases). Endoscopic dilatation was performed in 90 patients (89.1\% of cases) with Savary Gilliard bougies ( 87 cases) and hydrostatic balloons ( 3 cases). The average number of dilatation sessions was 1.69 . In 10 patients (11.1\%), refractory stenosis was observed. This stenosis could be resolved after further dilatation in 8 cases before the 8 th session. In 2 patients, dilatation failed. Conclusion: Benign oesophageal strictures in our digestive endoscopy centre in Senegal mainly affect young adults, with a predominance of women. Diagnosis is often late. Cervical oesophageal rings in the context of Plummer-Vinson syndrome are the main cause. Oesophageal dilatation with bougies is of great therapeutic value.

\section{Keywords}

Stenosis, Oesophagus, Plummer-Vinson, Dilatation

\section{Introduction}

Benign oesophageal strictures are defined as narrowing of the oesophageal lumen not directly related to neoplastic pathology.

Their prevalence is not well defined but they are frequently encountered during endoscopic practice [1] and are often responsible for an alteration in the quality of life of patients.

Depending on their morphology, stenoses can be considered simple or complex.

In Africa, particularly in sub-Saharan Africa, patchy studies have shown a higher frequency of Plummer-Vinson syndrome and caustic stenosis, probably related to poor socio-demographic and economic conditions [2] [3].

In Senegal, to our knowledge, no study has assessed the epidemiological, diagnostic and therapeutic aspects of benign stenoses in a comprehensive manner.

It is in this context that we conducted this retrospective, descriptive and analytical study over 3 years (January 1, 2015 to December 31, 2017) in the Hepato-Gastroenterology Department of the Idrissa Pouye General Hospital (HOGIP) in Dakar.

The general objective was to determine the epidemiological, diagnostic and therapeutic aspects in the digestive endoscopy department of the General Idrissa Pouye Hospital.

\section{Patients and Methods}

This was a retrospective descriptive and analytical study based on reports of upper GI endoscopies performed at the GI endoscopy unit between January 1, 2015 and December 31, 2017. 
We collected all upper GI endoscopy reports documenting to a benign looking esophageal stricture.

EOGD reports with missing data such as age, sex or indication were not included. Similarly, patients with suspected malignant stenoses in whom pathological findings were not found or were concluded to be neoplastic were excluded.

The data were collected on a pre-established form. They were entered using sphinx software version 5.1.0.2. The data were analysed using SPSS (Statistical package for Social Sciences) software. We used the chi-square test and Fisher's test for the comparison of proportions of qualitative variables and Studer's T-test for the comparison of quantitative variables. The threshold of positivity was set at 0.05 .

\section{Results}

During the study period, 5040 patients underwent oesogastroduodenal endoscopy. We collected 101 endoscopy reports that concluded to be non-neoplastic oesophageal strictures. The prevalence of benign stenosis was $2.1 \%$.

The mean age was 34 years with extremes of 2 and 83 years. The age group between 20 and 40 years represented $40.6 \%$ of the population (Figure 1).

There was a female predominance with a sex ratio of 0.38 (73 females).

Clinically, dysphagia, the main symptom, was present in 87 patients (86.1\% of cases) with a dysphagia score greater than or equal to 2 (able to swallow only semi solid foods) in 51 patients (50.5\%).

Epigastric pain with esophageal ulceration was noted in 12 patients (11.9\%).

Endoscopy showed stenosis of the upper third of the oesophagus in $81 \mathrm{pa}-$ tients (76.4\%) (Figure 2). The stenosis was impassable in 53 patients (60.9\%). The most common cause of benign stenosis was the Plummer-Vinson syndrome ring. It was observed in 71 patients, or $70.2 \%$ of the population. Caustic stenosis was the next most common cause, occurring in 19 patients, 18.8\% (Table 1).

Therapeutic management was by endoscopic dilatation with Savary and Gilliard

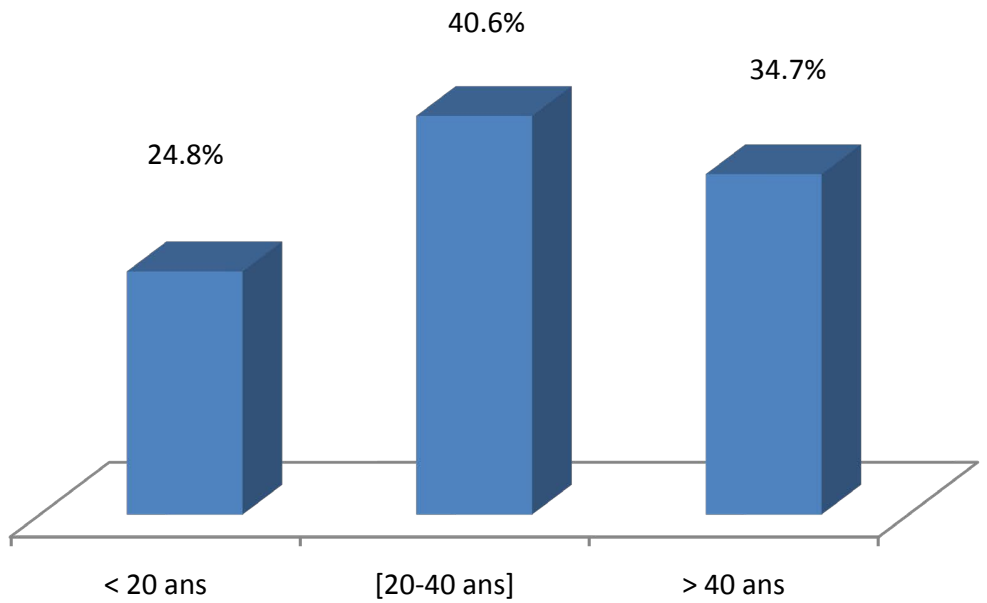

Figure 1. Distribution of patients by age group. 


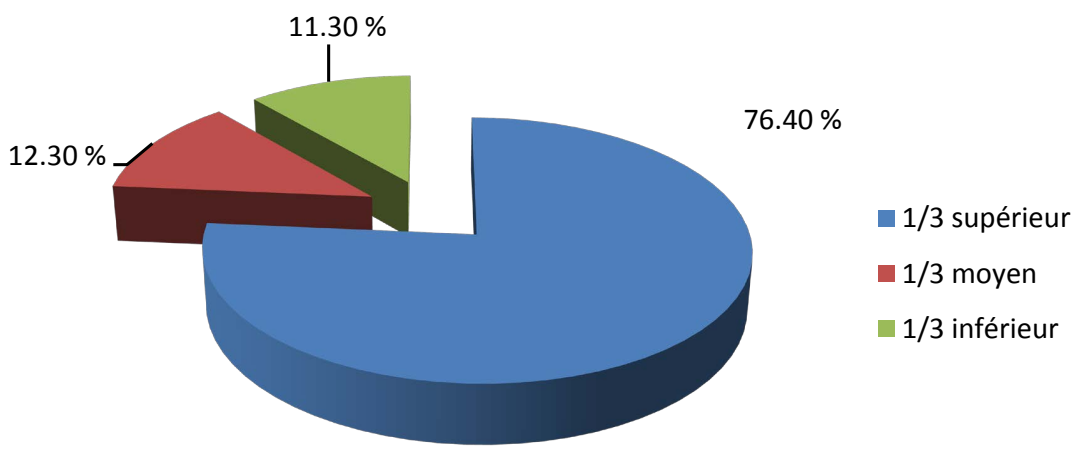

Figure 2. The different sites of stenosis.

Table 1. Different causes of stenosis.

\begin{tabular}{ccc}
\hline Types of stenosis & Numbers & Percentages \\
\hline Plummer Vinson & 71 & 70.2 \\
Caustic stenosis & 19 & 18.8 \\
Schatzki's ring & 4 & 3.9 \\
Congenital ring & 2 & 1.9 \\
Post-surgical stenosis & 2 & 1.9 \\
Peptic stenosis & 1 & 0.9 \\
Radiation stenosis & 1 & 0.9 \\
Infectious oesophagitis & 1 & 0.9 \\
Total & 101 & 100
\end{tabular}

bougies in 87 patients and hydrostatic balloon dilatation in 3 patients. In the remaining 11 patients, endoscopic dilatation was not performed. These were mild stenoses that were easily collapsed in asymptomatic patients.

Of the 90 patients who underwent endoscopic treatment, $80(88.8 \%)$ had a favourable outcome. The average number of dilatation sessions was 1.69 .

In 10 patients $(11.1 \%)$, refractory stenosis was observed. This stenosis could be resolved after further dilatation in 8 cases before the 8th session. In 2 patients, dilatation failed.

In multivariate analysis, there was a statistically significant association between female gender and the Plummer Vinson ring $(P=0.037)$, as well as between age $<40$ years and the Plummer Vinson ring $(\mathrm{P}=0.01)$.

\section{Discussion}

The age of our patients ranged from 2 to 83 years with an average of 34 years. Sixty-six patients (65.3\%) were younger than 40 years.

In the series by Cherquaoui et al. [4] in Morocco and Lahcene et al. [5] in Algeria, the mean age was 32 and 35 years respectively.

In the West, higher mean ages were reported. Indeed, Lecleire et al. [6] in France reported an average age of 68 years for refractory benign stenosis. 
This difference could be explained by the fact that in the West, peptic strictures are the leading cause of benign strictures [1], and these most often occur at a relatively advanced age, due to the increasing frequency of GERD with age [7]. Plummer-Vinson syndrome and caustic strictures, which are very common in Africa, occur most often in young people [3] [8] [9].

A female predominance was noted in our study with a sex ratio of 0.38 . Similar results were reported in different African studies by Bel Hadji Mabrouk et al. [10] in Tunisia and Lahcene et al. [5] in Algeria. Rare African studies have reported a male predominance: Oluwole et al. [11] in Nigeria.

In the West, the sex ratio varied greatly depending on the series [12] [13].

These differences can be explained by the aetiology of benign stenosis in different series. Indeed, Plummer-Vinson syndrome, the leading cause of benign oesophageal stenosis in Africa, is much more frequent in female subjects. Indeed Dia et al. [3] and Fall et al. [9] found a sex ratio of 0.21 and 0.1 respectively. In the rare African studies where a male predominance was noted, caustic stenosis was the predominant etiology [14] [15]. In the West where peptic stenosis is very common [1], the risk factors for peptic stenosis are not influenced by gender.

Clinically, dysphagia was the most frequent finding. It was present in 87 patients, $86.1 \%$ of the population. In all series, dysphagia was present and its frequency varied between $70 \%$ and $99 \%$ [3] [16]. The oesophagus is a cylindrical muscular-membranous duct and any significant reduction in the calibre of its lumen will inexorably lead to difficulty in swallowing.

At endoscopy, the stenosis was located in the upper $1 / 3$ of the oesophagus in $76.4 \%$ of cases in our study.

These results are similar to those found in the study by Ndayikeza et al. [15] in Morocco with involvement of the upper $1 / 3$ of the oesophagus in $48.8 \%$ of patients.

In western series where peptic stenosis is the primary reported cause, the lower $1 / 3$ of the oesophagus is the most common site of benign stenosis.

In our series, $60.9 \%$ of the cases of stenosis were unable to be passed with an endoscope.

In the studies by Cherquaoui et al. [4] all patients had an impassable stenosis at endoscopy.

Similarly, in the study by Bel Hadji Mabrouk et al. [10], 60\% of patients had an impassable stenosis.

These results can be explained by the fact that patients often consult late, at a stage when the stenosis is very tight, responsible for disabling dysphagia.

Plummer-Vinson syndrome was the most frequent cause of benign stenosis in our study with 71 patients affected.

This condition is not rare in Senegal. Indeed, Dia et al. [16] in 2019 reported a series of 186 cases collected in 10 years.

Other series have been reported in North Africa [17] [18].

In the West, this syndrome was common in the first half of the 20th century but currently it has become extremely rare [12]. 
A relationship was found between gender $(P=0.037)$, age $(P=0.00)$ and the occurrence of Plummer-Vinson syndrome in our study; Plummer-Vinson syndrome occurred in younger women.

The most widely accepted theory of the origin of this syndrome is that of martial deficiency with hypersensitivity of certain cells of the oesophageal mucosa [12].

In our regions, nutritional deficiencies, particularly in iron, are frequent. They mainly affect women due to several factors: blood loss during menstruation, multiple pregnancies and breastfeeding. All these factors contribute to the occurrence of Plummer-Vinson's disease in women during the genital period.

Therapeutically, instrumental treatment by endoscopic dilatation was performed in $89.1 \%$ of cases in our study. All patients were dilated with bougies.

In several studies, dilatation remains the first-line treatment [19] [20]. The efficacy of both the Savary-Gilliard candles and the hydrostatic balloon is the same [20].

The evolution was favourable because out of 90 dilated patients only 8 cases of refractory stenosis were noted, including 2 cases of failure. No complications were noted during our study. Patients with Plummer-Vinson disease had a favourable outcome with an average of 1.2 dilation sessions. These results are similar to those in the literature where the average varies from 1 to 2 dilatation sessions [3] [18].

Patients with caustic stenosis had a less favourable evolution with an average of 2.6 sessions. These results are similar to those of the study by Mohamed et al. [21] in Morocco with an average of 2.6 sessions. Seydou et al. [22] report in their study in Mali an average of 5 dilatation sessions. This can be explained by the fact that caustic stenoses are generally very fibrous, complex and most often require iterative dilatation sessions.

\section{Conclusion}

Benign oesophageal strictures in our digestive endoscopy centre in Senegal are mainly found in young adults, with a predominance of women. Diagnosis is often late. Cervical oesophageal rings in the context of Plummer-Vinson syndrome are the main cause. Oesophageal dilatation with bougies is of great therapeutic value.

\section{Conflicts of Interest}

The authors declare no conflicts of interest regarding the publication of this paper.

\section{References}

[1] Bulois, P. (2012) How to Manage Benign Oesophageal Strictures in Adults. Masson 3rd Edition, FMC-HE (Association Française de Formation Médicale Continue en Hépato-Gastro-Entérologie), POST’U 2012, Paris.

[2] Bakari, G., Imane, B., Loubna, B. and Abdellah, E. (2014) Endoscopic Treatment of 
135 Plummer-Vinson Cases: A Pilot Experiment. Gastrointestinal Endoscopy, 80, 738-741. https://doi.org/10.1016/j.gie.2014.05.332

[3] Dia, D., Diouf, M.L., Mbengue, M., Diouf, G., Bassene, M.L., Fall, S., Diallo, S. and Pouye, A. and Moreira Diop, T. (2010) Plummer-Vinson Syndrome: Clinical, Paraclinical and Therapeutic Aspects of 19 Cases in Dakar. Médecine d Afrique noire, 57, 189-192.

[4] Cherquaoui, H., Samlani, Z. and Ouabaha, S. (2016) Endoscopic Dilatation of Benign Esophageal Strictures: About 70 Cases. Poster 426, JFHOD 2016 Edition, French National Society of Gastroenterology, Paris.

[5] Lahcene, M., Oumnia, N., Matougui, N., Tebaibia, A., Boudjella, M. and Touchene, B. (2008) Instrumental Dilatation of Benign Esophageal Strictures in Adults: A Review of 277 Cases. Endoscopy, 40, 241. https://doi.org/10.1055/s-2008-1066971

[6] Lecleire, S., Alhameedi, R., Duclos, A., Melchoir, C. and Ducrotté, P. (2017) Biodegradable Prosthesis for Benign Refractory Stenosis (SORBE): Preliminary Results of the SFED Observation. Poster 184 JFHOD 2017 Edition, French National Society of Gastroenterology, Paris.

[7] Savary and Chevrel, B. (1988) Elements of Epidemiology of Digestive Diseases. Les oesophagites. Medico Chirurgicale, 17, 2-8.

[8] El Ghmari, A., Abid, H., Lahmidani, N., Lahlali, M., Lamine, A., El yousfi, M., Elabkari, M., Ibrahimi, S.A. and Benajah, D.A. (2021) Plummer-Vinson Syndrome: about 50 Cases. Oral Communication 000212, JFHOD 2021 Edition, Société Nationale Française de Gastroentérologie, Paris.

[9] Fall, F., Gning, S.B., Ndiaye, A.R., Diallo, I., Diedhiou, I., Sarr, A. and Fall, B. (2011) Plummer-Vinson Syndrome Retrospective Study of 50 Cases. Journal Africain d Hépato-Gastroentérologie, 5, 259-263. https://doi.org/10.1007/s12157-011-0340-9

[10] Bel Hadj Mabrouk, E., Ayadi, S., Ayari, M., Zaimi, Y., El Jeri, K., Said, Y., Mouelhi, L. and Debbeche, R. (2018) Endoscopic Management of Benign Esophageal Strictures. Oral communication 000391, JFHOD, Société Française de Gastroentérologie, Paris.

[11] Oluwole, G. and Toriola, F.S. (1978) Benign Esophageal Stricture in a Tropical African Population. Journal of the National Medical Association, 70, 497-499.

[12] Novocek, G. (2006) Plummer Vinson Syndrome. Orphanet Journal of Rare Diseases, 1, Article No. 36. https://doi.org/10.1186/1750-1172-1-36

[13] Dhooge, M., Vuarnesson, H., Lambert, J., Baudrey, C., Chirica, M., Lourenço, N., Munoz, N., Allez, M., Cattan, P. and Gornet, J.M. (2012) Interest of Endoscopic Dilatation in Caustic Esophageal Strictures. Endoscopy, 44, Article No. 005954. https://doi.org/10.1055/s-0032-1305692

[14] Bassene, M.L., Diouf, M.L., Diallo, S., Dia, D., Mbengue, M., Halim, A., et al. (2012) Caustic Digestive Lesions. Contributions of Endoscopy in the Diagnosis and Treatment in the Endoscopy Centre of CHU Aristide Le Dantec. Journal Africain d Hépato-Gastroentérologie, 6, 179-182. https://doi.org/10.1007/s12157-012-0384-5

[15] Ndayikeza, L., Ouahid, S., Azali, Y., Miyabe, F., Radouane, I., Touibi, A., Berrag, S., Adioui, T., Tamazaourte, M. and Aourarh, A. (2015) Management of Benign Esophageal Strictures. Oral Communication 000997, JFHOD, Société Nationale Française de Gastroentérologie, Paris.

[16] Dia, D., Gueye, M.N., Diallo, S., Bassene, M.L., Mbengue, M., Diouf, M.L. and Diouf, G. (2019) Plummer-Vinson's Syndrome: An Enigma in Senegal. Journal of Gastroenterology, Hepatology and Endoscopy, 4, Article ID: 1051.

[17] Ben Gamra, O., Mbareck, C., Mouna, C., Zribi, S., Zainine, R., Harigo, I. and El 
Khedima, A. (2007) Plummer-Vinson Syndrome. La Tunisie médicale, 85, 402-404.

[18] Chakkor, A., Salihoun, M., Acharki, M. and Kabbaj, N. (2018) Outcomes of Endoscopic Dilation in Plummer Vinson Syndrome. Endoscopy, 50, 313-314.

[19] Michael, D., Bichard, P. and Frossard, J.L. (2016) Benign Esophageal Strictures: Which Therapeutic Approach? Revue Médicale Suisse, 12, 1410-1414.

[20] Ouarrach, H., Pratic, F., Ouaba, S., Samlani, Z. and Krati, K. (2017) Endoscopic Treatment of Benign Esophageal Strictures. JFHOD 2017 Edition, Poster 170, French National Society of Gastroenterology, Paris.

[21] Mohamed, B. and Iman, B. (2015) Endoscopic Dilatation of Caustic Esophageal Strictures in 42 Cases. JHFOD 2015 Edition, Poster 311, French National Society of Gastroenterology, Paris.

[22] Seydou, T., Abdoulaye, O.M., Xing, L., Zi, S.Z., Sekou, K., Wen, Y.S., et al. (2016) Contribution of Endoscopic Means in the Dilatation of Caustic Esophageal Strictures. The Pan African Medical Journal, 23, Article No. 24.

https://doi.org/10.11604/pamj.2016.23.24.8506 